Revista Eletrônica Geografar, Curitiba, v. 2, Resumos do VI Seminário Interno de Pós-Graduação em Geografia, p. 08-08. Junho/2007

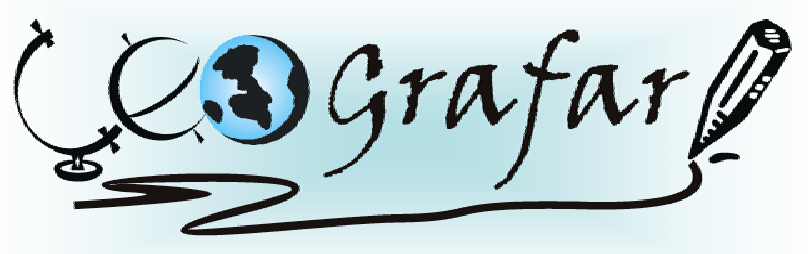

Revista Eletrônica do Programa de Pós-Graduação em Geografia - UFPR

\title{
SANTA FELICIDADE - ENTRE CARROS, RUAS E AVENIDAS: TRILHAS URBANAS PARA PÉS CAMINHANTES
}

\author{
ANGÉLICA MACEDO LOZANO LIMA ${ }^{1}$
}

A pesquisa, que se realiza em Santa Felicidade (Curitiba), é uma experiência onde ocorre o "ato de andar pelas ruas", para perceber e vivenciar relações entre caminhantes do bairro e o fluxo de veículos, observando suas atitudes (as ruas), construídos (quase sempre), sem os critérios necessários que permitam às pessoas sentir prazer em "ir a pé" aos lugares. Utilizaremos como bases teóricas e metodológicas a Geografia Cultural com aporte fenomenológico referenciando autores como PONTY, DARDEL, BACHELARD, HUSSERL, entre outros. Ao refletir sobre o "ritmo", fez-se a opção pelo slow movement, que prega a volta ao "ritmo natural do homem", já que atualmente encontramos pessoas andando entre carros e motos, cuja velocidade se constitui em uma violência para os sentidos humanos. Esses aspectos permitirão desenvolver uma abordagem sobre o ritmo/tempo: o ritmo da vida. Na cidade, quase não há lugares para andar a pé, a não ser nos parques. Prescindimos ainda do aporte de THOUREAU, para refletir sobre o "caminhar".Trabalhos de campo, pesquisa de gabinete, um arquivo fotográfico, mapas mentais e um "diário de campo", pretendem mostrar um "diagnóstico" sobre as atitudes dos caminhantes e condutores dos veículos e sua influencia na vida do bairro. Além desse diagnóstico, pretende-se identificar alguns problemas como a falta de espaços para caminhar, a falta de sinalização para veículos e pedestres, a diferença entre as ruas do bairro (centrais e periféricas). Pretende-se apresentar as relações das pessoas com o movimento dos diversos veículos e sua visão como caminhantes, atrelando a essas análises o tempo/ritmo, acelerado no caso dos veículos em contraponto ao ritmo do homem, comparado aos ritmos da natureza, mais lentos. Objetiva-se, dessa forma, identificar os motivos pelos quais as pessoas deixam de fazer percursos a pé, de ver a cidade, ver a vida, de aumentar os relacionamentos enfim, de viver a cidade.

Palavras-chave: Geografia e representação, percepção, trilhas urbanas e caminhantes.

${ }^{1}$ Mestranda em Geografia - UFPR - email: gelilozano@yahoo.com.br Orientadora: SALETE KOZEL 